\title{
Multiculturalism in the Australian Tropics
}

\section{Dawn May}

Henry Reynolds. North of Capricorn: the Untold Story of Australia's North.

Crows Nest: Allen and Unwin, 2003.

pp 220, illus, \$49.95 hb. ISBN 1865080306

\section{North of Capricorn: The untold Story of Australia's}

North is the latest publication by Henry Reynolds, one of Australia's foremost historians and one of the academy's most prolific writers. Several of his books have won prestigious awards and most have contributed to important aspects of political debate in this country, none more significant than the Mabo and Wik judgements.

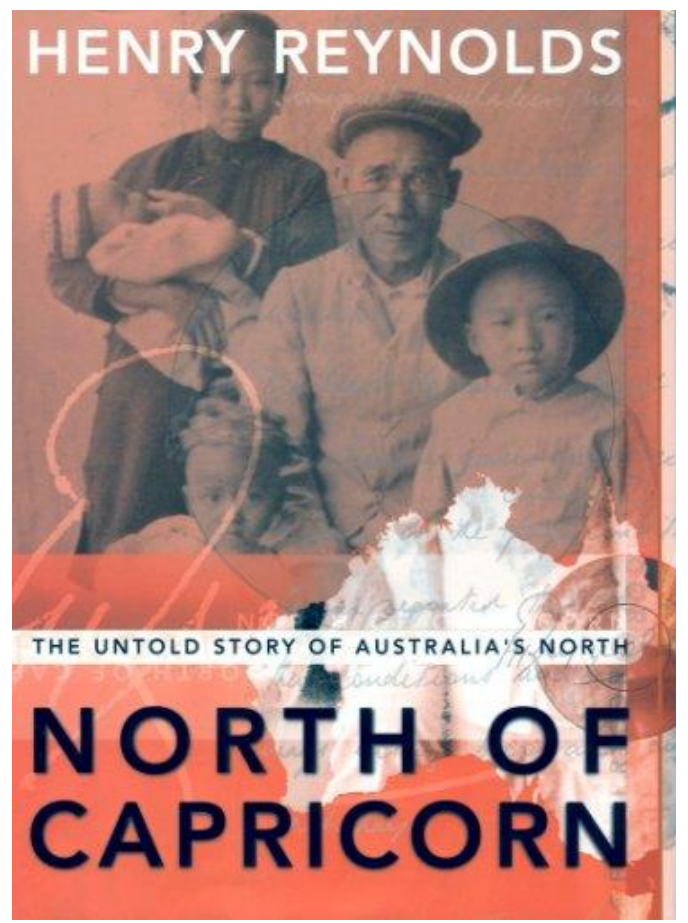

The sub-title of the book is The Untold Story of Australia's North and this is quite a claim given that North Queensland in particular has been subjected to a huge amount of historical analysis. James Cook University's History department alone has produce some 50 publications on aspects of the region's history. But this is indeed the 'untold story'. Reynolds develops a highly original account because of his expertise as a skilled researcher and his ability to stand back from the detailed material and see the big picture.

Reynolds demonstrates that at the time of federation, north of Capricorn was a decidedly different world from south of Capricorn. Back in the 1970s several historians were engaged in a debate about Queensland's distinctiveness. Some argued that one of the things that made Queensland different from other states was that its population was more homogeneous. Clearly this was not always the case in the north. At the turn of the C20th, it was a vibrant multiracial society. Indeed, as Reynolds argues, the region had more in common with Melanesia and Southeast Asian than with the temperate south. This created problems however for the new federal parliament developing policies aimed at maintaining the 'purity of race' and keeping Australia white. 
At the time of federation in 1901 it is estimated that there were at least 12,000 Aboriginal people living on Cape York who had had no contact with the white population, a situation that was similar in other parts of northern Australia. Nevertheless, by that time many other Aborigines lived in close proximity to Europeans and Asians and black labour was indispensable to the lives of the non-Aboriginal population. Reynolds suggests that the year 1900 'may have marked the moment when Aborigines were most involved with white people.'

Conflict had come to an end in many districts. There were still significant [Aboriginal] communities although the small number of children in the camps presaged future demographic decline, which continued until the middle of the twentieth century. The Queensland Aborigines Protection legislation of 1897 had only started to impact on northern society by 1900 and similar legislation in Western Australia and the Northern Territory was still some years away. (p34)

While Aboriginal labour was the backbone of the northern Australian pastoral industry, South Pacific Islanders provided practically all the labour for the foundation and consolidation of the sugar industry. In 1901 non-Europeans in the Cardwell and Cairns Census Districts made up 40 per cent of the population. Chinese were the largest non-European group - just under one-fifth of the total.

Southern contemporaries often commented scathingly on the multicultural nature of Cairns stating that the town was where Europeans 'ate with the Chows'. Many of these Chinese had come to work on the northern gold fields but were eventually pushed out of mining by restrictive legislation. Those that remained became pioneers, in particular of tropical agriculture including bananas, maize and sugar cane. They commonly leased and cleared virgin land before it was taken over by Europeans with their ploughs. Chinese worked in many other areas as well. In northern towns like Darwin and Cairns, they resisted the pressure to live in enclaves. Wealthy Chinese put on banquets that were attended by many of the white civic leaders. They also met visiting dignitaries. For instance in 1903 the Cairns Chinese community gave one of two official receptions for visiting Governor, Sir Herbert Chermside.

While there was a sizable Chinese population in Cairns and Darwin, on Thursday Island and Broome, Japanese easily outnumbered Europeans and in 1897 it was argued that there was 
'every appearance of Thursday Island and its vicinity becoming a Japanese colony'. Broome, with the most heterogeneous collection of nations, creeds and languages, was considered a 'veritable ethnological museum'. The predominance of Japanese in the pearling industry caused deep concern amongst supporters of a White Australia policy and unsuccessful efforts were made to replace the Asian workforce with white divers.

Southern visitors to the north found the flourishing multiracial towns where Asians often outnumbered Europeans, a confronting experience. It was also confronting for our politicians. Reynolds writes that as the members of the first federal parliament debated the Immigration Restriction and Pacific Island Labourers Bills they emphasised the central importance of the White Australia Policy. 'They believed they were making law, making history and defining the shape of the new nation.' (p159) Unity of race was to be a foundation plank in the new nation. Even liberal thinkers such as Alfred Deakin argued that it was part of the first principles by which the Commonwealth was to be administered and guided. He observed that members on both sides of the parliament, with the people behind them, were 'all united in the unalterable resolve that the Commonwealth of Australia meant a white Australia.' (p160) Prime Minister Barton declared that he did not think 'that the doctrine of equality of man was really intended to include racial equality.'

Clearly then, these successful multiracial societies such as those functioning in Cairns, Mackay, Broome and Darwin were a threat to policies being formulated in the new national parliament. Many believed that it was better to leave the tropics undeveloped than have them developed by alien races. Racial purity was to take precedence over economic development. And so Kanakas were repatriated back to the Pacific Islands in 1906, severe restrictions were placed on the entry of Asians into Australia and Aboriginal groups were increasingly isolated on government settlements and church missions.

All these policies aimed at maintaining racial purity impacted on the economic development of the north. Reynolds argues that Australia lost much of its entrepreneurial drive and flair and sheer hard work of Chinese, Japanese and Filipino immigrants who had been so important in the C19th.

The book also makes a contribution to a number of academic debates: is Australia, or North Australia at least, part of Asia; the appropriateness of multiculturalism as a government policy; and the price a nation can play in denying human rights to immigrants. 
Reynolds' arguments in this book are convincing. The book is highly readable and should appeal to readers from all walks of life. More importantly it helps us to understand who we are. 